\title{
Future of US-China Relations: Conflict, Competition or Cooperation?
}

\author{
Syed Muhammad Saad Zaidi ${ }^{1} \&$ Adam Saud ${ }^{2}$ \\ ${ }^{1}$ Ph.D. International Relations Scholar, Bahria University, Islamabad, Pakistan \\ ${ }^{2}$ Associate Professor/Head of International Relations Cluster, Department of Humanities and Social Sciences, \\ Bahria University, Islamabad, Pakistan \\ Correspondence: Syed Muhammad Saad Zaidi. Tel: 92-333-551-5965. E-mail: saadz93@hotmail.com
}

Received: April 9, 2020

Accepted: May 12, 2020

Online Published: June 12, 2020

doi:10.5539/ass.v16n7p1

URL: https://doi.org/10.5539/ass.v16n7p1

\begin{abstract}
In contemporary times, the geo-political agenda and geo-economic strategy of the world is being dominated by the ongoing US-China hegemonic competition. Where the United States is trying to prolong the 'unipolar moment' and deter the rise of China; China is trying to establish itself as the hegemon in the Eastern hemisphere, an alternate to the US. The entirely opposite interests of the two Great Powers have initiated a hostile confrontational competition for domination. This paper seeks to determine the future nature of the US-China relations; will history repeat itself and a bloody war be fought to determine the leader of the pack? or another prolonged Cold War will be fought, which will end when one side significantly weakens and collapses? Both dominant paradigms of International Relations, Realism and Liberalism, are used to analyze the future nature of the US-China relations.
\end{abstract}

Keywords: US-China Relations, Hegemonic Competition, Great Power Politics, Realism, Liberalism

\section{Introduction}

The year 1989 was a watershed moment in history, in February 1989, the Soviet forces withdrew from Afghanistan, indicating United States' (US) victory in the war among the hegemons. Soon after, in November 1991, the infamous "Berlin Wall" fell, which highlighted that communism had lost in Eastern Europe, Soviet Union's (USSR) stronghold. Consequently, soon after, in December 1991, the USSR finally collapsed heralding the emergence of a unipolar world, with the US emerging as the sole Superpower of the world.

Political analysts in favor of the unipolar movement, like Francis Fukuyama, termed these two events, defeat of Soviet forces in Afghanistan and fall of Berlin Wall, to be the end of Great Power politics, with there being only one 'Superpower;' the US. (Fukuyama, 2006) Western ideological triumph over communism meant that more states were willing to democratize their governments, liberalize their economies and integrate into US-led world order. China and Russia being the only remaining Great Powers of note were significantly weaker than the US in terms of material capabilities, disallowing them from mounting a meaningful challenge immediately.

After 1989, the US foreign policy was no longer concerned with Great Power competition. Particularly, after the 9/11 attacks, a paradigm shift was observed in the US foreign policy, with it being primarily focused upon the global "War on Terrorism" in Afghanistan and Iraq as well as numerous interventions based on violation of human rights in Libya, Syria and Yemen. The US mainly focused its attention to the vital aspects that were threatening its hegemony; growing extremism and terrorism as well as nuclear proliferation. Less predisposed to perceive China as a future strategic rival, the post-9/11 world saw the majority of Great Powers "united by common dangers ... [and] increasingly ... by common values." (Bush, 2009)

In contemporary times, China's phenomenal rise to power has greatly challenged the unipolar moment. In merely three decades, 1978-2008, China transformed into the world's second biggest economy from a rural society. (Yang, 2013) Not only China rapidly grew economically, but also its political influence grew within the region in particular, and across the globe in general; which in turn created serious problems for the US to safeguard its interests as well as the interests of its allies and maintain the all-important "balance of power" in the region. Nevertheless, history clearly dictates that usually the rise of a Great Power accompanies hostility, rivalry and even war between the prevailing status quo power(s) and that emerging power. (Allison, 2017) Political analysts by referring to evidences, such as arms-buildup in the Asia-Pacific region, growing competition for political influence, and contending economic and ideological models followed and promoted by both China and the US; 
build their case of the beginning of another Cold War.

Friction between Beijing and Washington became more pronounced during George W. Bush's second tenure as the US President. Despite increased apprehensions, the relationship between the two states remained harmonious compatible on matters of interests if not of values. China's coziness with North Korea's regime added to the global consternation over its military buildup, especially after European arms sales were resumed with the Asian nation. With the US considering North Korea's regime to be rogue, Beijing's commitment to non-proliferation was called into question, when negotiations over North Korea's denuclearization were halted.

China going global, extending its reach economically and diplomatically towards the Middle East, Latin America, Europe and Africa, was most definitely of grave concern to the US hegemony, but what really sealed the deal and transformed China as a formidable challenger to the US hegemony were the ever-growing disagreements over currency values and trade balances between the two states. Not only the media created tremendous hype over the ever-growing demands of China on having a larger say in determining the global prices for raw materials and energy, but also it sensationalized the purchase of US companies by wealthy Chinese competitors. (Glaser, 2005) Given these economic dynamics, Jonathan Anderson end up labeling this period as "the end of the China love affair". (Anderson \& Keidel, 2005)

To this day, US policymakers continue to wrestle with the idea of a China peacefully integrated in the prevailing US-led liberal world order. According to John Glaser, Director of Foreign Policy Studies at the Cato Institute, "US-China bilateral relations will remain tentative in the near future." (Blatt, 2018) This is largely because the US, despite still being world's superpower, is currently experiencing a relative decline, in contrast to an indisputably "rising China." The two Great Powers of the $21^{\text {st }}$ century, US and China, maintain an apprehensive understanding, taking into account each other's power, and always wary each other's motives, while eagerly striving towards the prestige, global supremacy.

A rising China poses a serious threat to the global order, as China has repeatedly stated that the prevailing system needs to be replaced by a neutral system, which provides equal opportunities as well as delegates equal resources to all states of the world. (Ikenberry, 2015) It is still not clear if China's economy will retain its meteoric rise or if it will gradually simmer down. Convicting arguments lie on either side of this debate, it is possible that the future may be synthesis of a number of these arguments.

\section{Nature of Future US-China Relations - A Realist Perspective}

Realism, the oldest and most dominant theory of International Relations, is grounded on the principal that global politics is a struggle of self-interested countries for power and position under anarchy. (Jervis, 1998) When it comes to the future of the US-China relations, generally, the dominant view presiding amongst the realist school of thought is that a tight confrontational-competition will be observed among both states, with the global hegemon, the US having the upper hand. However, some realists are also of the view that history will repeat itself and a full-out war among the rising power, China, and the existing Superpower, the US, is inevitable. The merits and demerits of both arguments are analyzed below;

\section{Realist Optimists}

Generally, realists are thought to be pessimists, who view "the glass to be half empty than full." Also, they view the world to be in a constant state of anarchy where everyone is in conflict with the other for their survival. However, there exists a group within realists, referred as 'Realist Optimists,' who are slightly more optimistic regarding the future US-China relations. They contend that China's power is not increasing exponentially as claimed by many political analysts. More importantly, China does not have revisionist or radically expansionist tendencies like pre-war Germany or the Soviet Union. A modestly conservative China cannot escalate the security dilemma with the US; thus, preventing deterioration of bilateral ties.

\section{Limited Capabilities of China}

Most realists find the unfolding character of the US-China relations dependent on the "balance of power." Realists also note correctly that the US is still far more powerful than China, despite several decades of unprecedented growth. In some respects, like the world's largest army, China has indeed surpassed the US, but in case of a hostile confrontation, neither power is willing to bet its worth on changing/maintaining the balance of power. Realist Optimists claim that China is not as powerful as perceived by many, especially militarily, and that its growth in the coming decades would be much slower than predicted by many. (Harris, 2003)

For sustained growth in the economic and military spheres, China has yet to overcome a number of hurdles. In fact, the chances are high that the growth of China will decrease gradually over the next two decades as compared to the past two. Economic expansion will come under hindrance from internal social and political 
unrest. Even without potential turbulence, its growth will ultimately slow-down in the absence of competent, just, and open legal and financial institutions which require time to take effect. (Chang, 2002; Lardy, 2013; Rawski, 2001) Also, because of China's uneven development, Beijing will find it difficult to raise its military capabilities at the current rate.

As soon as President Trump took office, he indicated that the US would revisit its policies towards China, especially its economic policies. President Trump blamed the previous administrations economic strategies vis-à-vis China, which resulted in the mammoth $\$ 419.2$ billion trade deficit.(The People's Republic of China, 2018) Soon after, the Trump administration promulgated protectionist economic policies, specifically aimed at narrowing the US trade deficit with China, which were a success as the trade deficit shrank to $\$ 73.9$ billion. (Swanson, 2020)

Furthermore, China's unprecedented $10 \%$ annual growth rate, which it maintained for decades, ceases to exist, especially after the 2008 economic crisis which slowed the global economy substantially. China states that the reason for its slow growth rate is related to an increased focus on quality of products rather than quantity, rising wages, and shrinking working age population. (Balding, 2019) Apart from structural and economic factors, China's differences in organization, lower literacy rates, human rights record, and doctrinal development, may disallow China's from becoming a top-end military power. (Karmel, 2000; O’Hanlon, 2000)

Instead of catching up to the US in most measures of national power, much less surpassing it, China is bound to lag, and the gap between the two states would widen. Thus, there exists negligible chances that Beijing will be able to mount a credible challenge to the US hegemony. Chinese leaders are forced to avoid a direct conflict with the US owing to their relative weakness; thus, ensuring global peace. (Pumphrey, 2002; Tyler, 1999)

For realist optimists, the US is now so powerful that its unipolar status is fundamentally incontestable. In what would be a historical first, this unipolar world order could refute traditional assumptions of anarchy and the expectations on international political conduct may no longer be applicable. Neither China, nor a coalition of dissenters, can harness the necessary resources for challenging the US dominance. Instead of choosing the losing side, most states would be content to become part of the US-led liberal world order.

Most importantly, with powerful hegemon in place, like the US, states have little room to exploit misperception or fall prey to miscalculation. No longer will complex calculations need to be made to determine uncertain outcomes of a head-on conflict with the US as it is pretty obvious the odds are stacked in America's favor; thus, refuting the idea that China or its leaders could stand to gain much from a war with the US. (Brooks \& Wohlforth, 2002; Wohlforth, 1999)

\section{Limited Aims of China}

While majority of the realists draw conclusions regarding state actions and intentions from the state's capabilities, not all realists tend to follow this line of thought. Similarly, the universal assumption that China is an emerging power and all emerging powers tend to be aggressively expansionist or assertive, is not shared by all proponents of Realism. Intent is not necessarily a reflection of capabilities as Randall Schweller notes. Not all emerging powers are displeased with the status quo equally; thus, the magnitude of their ambitions vary. While, revolutionary expansionist powers look to the overthrow the prevailing international system. The modest emerging powers might be progressives, seeking by only making minimal alterations to the existing system instead of radically changing it. (Schweller, 1999)

Unlike the 1950's and 1960's, today's China is no more a revolutionary power and has indeed absconded from the idea of disseminating communism throughout Asia. In fact, all its actions since then have been away from the "Marxist-Leninist-Maoist" it once embodied. China's revision of the status quo is relatively restricted and chief among its objectives would be the reunification of Taiwan with the mainland, settlement of border disputes, and its maritime claims in the South and East China Seas to be recognized by the international community. Could that these forefront issues be peacefully concluded, China would consider being a part of the prevailing status quo. (Goldstein, 2005; Johnston, 2003; Nathan \& Ross, 2009)

Many western China-observers agree with the Chinese narrative, apart from a few exceptions, China harbors no historical tendency or explicit intention for territorial expansion. Although far from being a status quo player, it is still a limited actor with conservative goals. Setting aside the paranoia, associated with the rapid frequency at which its capacity has grown, China's ambitions in actuality shows limited possibility for conflict with the US.

\section{Negligible Security Dilemma}

The impact of the security dilemma remains valid on the US-China relations, regardless of China's actual power potential. Mutual fear and distrust are an objective reality, which in turn triggers an arms race. For 'Realist 
Optimists' the presence of a number of counterbalancing mechanisms, such as "Mutually Assured Destruction" (MAD), which exists today can offset the dangers of misperception and potential clashes.

According to some observers, post-Cold War East Asian dynamics are inherently bipolar, between US and China, owing to the Soviet disintegration and Japan's extended economic sluggishness. With the US showing continuous willingness to engage with its East Asian allies and China continuing to build up power, the bipolarity trend is expected to become more pronounced in the future.

Given the experiences of the Cold War and the "Neo-Realist" theory of Kenneth Waltz, bipolar Asia can lend a great degree of stability in spite of the tensions. The two prominent powers, US and China, would look at each other with suspicion, but out of the intent focus on each other, they will prop up a system that ensures little room for miscalculation about their respective capabilities and motives. Given the geographic distance between the bipolar powers, populated by additional states, the possibility for any drastic power shifts, such as third parties' allegiances, is dramatically reduced. (Waltz, 2010; Ross, 1999)

As both states, China and the US, have nuclear weapons the phenomena of MAD kicks in, i.e. both states shall refrain from waging war against the other, as an outright conflict assures destruction of both the states; thus, states opt for a Cold War. Avery Goldstein claims that "the the dangers associated with China's arrival as a full-fledged great power will be limited." For Goldstein the US and China are already engaged in an "easily established [relationship] of mutual deterrence that provide[s] not only a robust buffer against general war, but also a strong constraint on both limited war and crisis behavior." (Goldstein, 1998; Jervis, 1990)

Moreover, Realists optimists like Michael McDevitt and Robert Ross understand that another structural factor; geography, also stabilizes the US-China relation. The US is the strongest maritime power across the globe. With most of its interests located offshore in Northeast and Southeast Asia, its natural influence complements that of China which is predominantly a land power. China's natural area of influence extends more towards Central Asia and mainland Southeast Asia, but it is maritime influence covers Taiwan, Korean Peninsula, and the Spratly Islands. The Cold War era security dilemma displayed significant differences, the US and Soviet Union often had overlapping or adjoining spheres of influence in the Middle East, Latin America, Europe and Africa. Such a situation was likely the reason behind the dangers produced out of competition especially in Europe. (Ross, 1999; Tao, 2018)

For David Denoon, Professor of Politics at the New York University, China still cannot contest the US militarily, the most likely outcome would be on of long-term competition, not war. (Blatt, 2018) If the US can implement budgetary strategies while countering trade deficits and abstain from pointless military conflict, Sino-American ties would remain stable albeit strained. If the US takes its economy for granted or pulls out of Asia, then China will most possibly challenge its commitments and conflict could easily triggered through proxy actors

When considering tactical advantage, the US happens to be in a better position. An expansionist or revisionist China can be deterred, as the increasing interaction of the Chinese with the outside world added to the fact that they are not irrational people, which can be crucial in coming to an eventual coexistence. The onus of responsibility lies with the US and its allies to set up an adequate deterrent to Chinese troublemaking, maintain America's material power, display the American resolve to use that power conditionally, and instill within Beijing the belief in the US dominance and will.

\section{Realist Pessimists}

Furthest off on the political spectrum from liberals are the Realist Pessimists. Where the former believe that history is progressive towards prosperity and peace, Realist Pessimists believe the inherent qualities within nature makes history a cyclical process of power domination and survival. Realists claim that anarchy is an unavoidable reality of the global system, which they use to describe a lack of any higher central power over sovereign states for resolving their disputes, dispensing justice and imposing order. According to Realist, peace is the exception to the rule (conflict) and because the anarchic system is one where states are the principal unitary actors, who help themselves, material strength and distribution of military capabilities are naturally decisive in dictating the manner of affairs between them. (Mearsheimer, 2003; Waltz, 2010)

\section{China a Rising Power?}

Ostensibly, Realist Pessimists are concerned with how an increasingly powerful China can change existing world order. The nature of US-China relations is, like everything else, hinged to relative power distribution. Economic might is a key indicator of 'national power.' Ever since 1978's famous economic reforms, China has transformed into the world's second largest economy, the world's largest in terms of 'Purchasing Power Parity' (PPP), in merely three decades. Not only China's 'Gross Domestic Product' (GDP) grew at an unprecedent rate of 
approximately $10 \%$ for three decades, but also its 'Gross National Product' (GNP) risen exponentially. (Wolf \& Chen, 2001) China's power not only stems from its economic might, but also from the sheer potential of its massive population and the productive implications of newer technology. Owing to the above stated facts, China is pretty likely to gain the position as the top global economy. However, the reliability of such prediction are very uncertain, since, China's economy was predicted to overtake the US round 2015. (Maddison, 1998)

An expanding economy ushers in the expansion of military capabilities, as was the case with every Great Power in history. With the fastest growing GDP and GNP, China has been able to heavily invest in its military, vastly upscaling its military offensive capabilities. The combined effect of increasing productivity, incomes, and technological prowess foreshadowed China's ability to purchase sophisticated foreign weapons as well as produce them indigenously. (Gill \& Kim, 1995) However, still China lags far behind militarily when compared with the US, which is in a league of its own militarily, as its military expenditure of 2018 was more than the combined military expenditure of the next 7 top military spenders of the world; China, United Kingdom, France, Russia, India and Saudi Arabia. (Artiga-Valencia, 2019) Although, as China's overseas involvement and regional power steadily expands, it would gradually put together more proficient military systems in the coming years, which make the increase the chances of a clash between the two states. (Medeiros et al., 2005)

\section{Ever-Increasing Interests of China}

Throughout the course of history, Realists have observed that rising powers have always caused trouble for the existing status quo powers. Regardless of whether the regime was democratic, the US, or autocratic, Germany, this fact holds true for all rising powers. "The external expansion of the United Kingdom and France, Germany and Japan, the Soviet Union and the United States coincided with phases of intense industrialization and economic development." (Huntington, 1991)

Realists cite several reasons for this logic. One of which is that whenever a state develops offensive capabilities, its leaders shift their focus on more expansionist interests seeking to influence happenings in their vicinity to a much greater extent. Rising powers are not only motivated to protect territorial boundaries, but also will often expand past them for reasons such as market access, procurement of materials, and seeking more favorable logistics; protection of overseas citizens, participation and defense of allies causes, and dissemination of values; and, more generally to have a say in in what legitimately constitutes regional and global affairs. Robert Gilpin summarizes this link between emerging powers and expanding influence, "A wealthier and more powerful state ... will select a larger bundle of security and welfare goals than a less wealthy and less powerful state." (Gilplin, 1981)

In a way of asserting themselves, emerging powers frequently undermine existing boundaries, intrastate norms, and orders of stature they were subject to when weaker. In China's case this is especially relevant as China's leaders tend to believe that they were unfairly exploited out of their fair share of the pie, robbed by foreign powers of what is rightfully theirs. Germany's rhetoric towards the early twentieth-century reflected their need for their own place in a budding international order, which brought them to clash with the established great powers, the progenitors and protectors of the existent world order at the time. (Choucri \& North, 1975)

While many mechanisms exist for dealing with the disputes arising between an expansionist/revisionist power and its already established counterparts; history shows that such disputes have rarely been settled peacefully. Usually, the status quo powers recognize the threat to their dominance and tend to use pre-emptive force, either unilaterally or through a coalition, to neutralize rising powers before they realize their complete potential. Where there was not enough momentum to pursue such a policy, status quo states are also known to appease challenger states seeking to subdue their ambitions and placate them through engagement within the world system to avoid costly wars. While such occurrences are quite rare and have mostly failed than succeeded, they do say something to the liberals' credit where conflict between states has been due to incompatible characters.

Sometimes emerging powers have been so radically expansionist that the existing Great Powers were not successful in appeasing them without effectively committing suicide, as the circumstances with Germany and Japan that led to World War II. On the contrary, the prevailing status quo powers may still be hesitant in making rational and practical concessions, even when emerging powers are not radical; leading to cycle of resentment and escalation. In short, while engagement/appeasement seems plausible in theory, it has proven to be difficult to implement practically. (Schweller, 1999)

On this note, the majority of realist pessimists like to conclude that given China's burgeoning economy and expanding military abilities, it is implausible for it to act wisely. Huntington, while making the correlation with similar cases of rapid domestic growth and outward expansion, expects China to "undoubtedly be moving into such a phase in the coming decades." (Huntington, 1991) Similarly, John Mearsheimer, predicts that, "China, 
like all previous potential hegemons, [will] be strongly inclined to become a real hegemon." (Mearsheimer, 2003)

The case that China is more likely to assert its dominance even if it means coming into conflict with other states could also be linked to its "Century of Humiliation," starting with the "Opium Wars" of mid- $19^{\text {th }}$ century and ending after World War II, when foreign powers were expelled from the mainland. This collective memory of China's recent past has also made its leaders and people highly conscious to perceived affronts to national prestige and particularly alert to peripheral threats. (Gries, 2004) The sore reminders of the $19^{\text {th }}$ and $20^{\text {th }}$ centuries, have led modern Chinese policymakers to be keenly intent on erecting a perimeter of control that would check such humiliations from happening again in the future. (Bernstein \& Munro, 1998)

China draws inspiration for its efforts to build a Sino-centric Asian system from even further back into the past, when it was for many centuries the chief power in Asia, before its decline and exploitation by the colonial powers of the time. As Beijing comes to terms with its growing power it will continue to seek out behavioral models and favorable conditions to reinstate China as East Asia's preeminent authority. (Eyraud, 2004; Kang, 2005; Mosher, 2002) A few US administration's organizations do think, in the realist pessimist manner, that China intends to replace the US as the preponderant power in East Asia. Given its longstanding policy of opposing the domination of Eurasia by any antagonistic power, the US certainly is prepared for a prolonged strategic rivalry in the Western Pacific. (Kissinger, 2002)

\section{The Extreme Security Dilemma}

Even if China's ultimate goal does not involve violently displacing the US from East Asia, the possible character of future US-China relations might still be influenced by the security dilemma. (Christensen, 1999; Jervis, 1978) Even if the political aims pursued by either power remains purely defensive, each side's efforts to augment its position and achieve its aims may still incite retaliation as is obvious in the various features of modern US-China affairs.

Taiwan's status is one such contentious issue with China intent on preventing Taiwan's secession and Washington being Taiwan's ally seeking to prevent a forced reunification. China may be content with issuing periodic threats to discourage secessionist rhetoric but given its unending military buildup the US fears that Beijing would try and achieve its objectives by force. Washington is thus continuously compelled to deter China by increasing military assistance to Taipei as well as taking other measures to demonstrate its willingness to intervene on Taiwan's behalf in case of an attack. Such efforts can have the opposite effect, fueling Beijing's fear of secession and might stimulate it to revamp military efforts to deter secession in turn, leading to an escalating cycle of competition. (Nathan, 2000; Roy, 2000)

China's deployment of ballistic missiles systems in the disputed South China sea can be a strategy for deterring Taiwan's independence declaration. But the expansion of China's strike capability within the Pacific theater poses an existential risk for Taiwan, Japan in particular, and the US and other competing states of the region in general. The US response of deploying "Theater Missile Defense" system (TMD) or a carrier group may seem like a measure of protection for its allies and interests in the Pacific region but appears highly threatening to the Chinese. China would focus on how such an act would damage its capacity to influence regional changes particularly if an US-coordinated TMD system was to include Taiwan. The consequent Chinese response to such developments could lead to them ramping up theater - and intercontinental-range attack abilities that would trigger anxiety in America over their purposes. (Christensen, 2000; McDevitt, 2000; Medeiros, 2001)

The United States government officials regard regional alliances as nodes of stability. Ever since the Cold War ended (1989), the US has been busy augmenting its relations with its traditional regional allies like Australia, Japan and South Korea; mostly due to its growing concern over mounting Chinese power. The 1990's were a period of expanding cooperation in Central, South-East and South Asia for the US, a trend only intensified by the 9/11 attacks and later the "Pivot to Asia Policy" (2011). Regardless of what commentators may say of the US intentions, China regards this activity as anti-Sino-centric and hostile to its interests. On occasion that China opposes US actions and alliances, or counters with its own diplomatic/economic overtures to Russia or other countries (Iran, Azerbaijan, North Korea), its actions are interpreted by the US as proof for hostile expansionist intent. (Friedberg, 2002; Shambaugh, 1999)

Military reporter and author of "Crashback: The Power Clash Between the US and China in the Pacific", Michael Fabey predicts that with the current policy trajectory of both China and America's navies, a clash is inevitable in the Western Pacific. (Fabey, 2017) Both countries have entirely divergent core doctrines that guide their military in the region. For the US, most airspace and sea lanes are international regions that should be kept open for the benefit of any nation. China, on the other hand believes that it holds a rightful claim to historically 
and contemporarily relevant 'Chinese territory' which ought to be recognized by the whole world.

Renowned political analyst, Graham Allison, in his most recent book "Destined for War: Can America and China Escape Thucydides's Trap?" predicts that US-China ties are bound to go into decline. (Allison, 2017) Having used the term "Thucydides's Trap," which explains that conflict is unavoidable whenever a rising power is poised to displace the existing status quo power. Throughout history, since ancient Greek times to date, sixteen notable Great Power/hegemonic competitions have taken place, out of which twelve have ended in devastating wars, the "Thirty Year War" and "World War I and II."

\section{Nature of Future US-China Relations - A Liberal Perspective}

Liberalism, a mainstream theory of International Relations, is based on an optimistic approach to global politics. Liberals believe that by applying reason and universal ethics to International Relations a more orderly, just and cooperative world order can be made. Furthermore, by empowering International Institutions and enforcing International Law anarchy and war can be minimized if not totally eradicated. (Doyle, 1986) Like realists, liberals too are divided into two groups on the future of US-China relations, one predicting cooperation-based US-China ties (Liberal Optimists), while the other forecasting hostile relations between the two states (Liberal Pessimists).

\section{Liberal Optimists}

Liberals are mostly optimists as they prioritize peace, cooperation, and dialogue between states. The US foreign policy has predominantly been defined by liberal values. With the fair share of the US policymakers being optimistic liberals, the question of future US-China relations for them would be one of convergence. Liberal optimists understand that world politics is progressive due to the mutually reinforcing power of three fundamental interrelated mechanisms; democratization, international institutions' and economic interdependence. (Doyle, 1997; Russett \& Oneal, 2002)

\section{Complex Economic Interdependence}

For liberal optimists, shared economic interests is the key to improve bilateral relations among states. War is harmful for trade and investment, whereas greater volumes of economic exchange creates more incentive for shunning conflict between two states; hence, usually rational states opt to avoid conflicts, refuting a zero-sum game strategy, while promote trade and investment, a positive-sum game approach.

Liberal optimists see the significant increase in economic exchange among the US and China from 1978 to the end of the $20^{\text {th }}$ century, when market reforms took place in China, as evidence supporting their argument. Bilateral trade exploded during this time from $\$ 1$ billion to around $\$ 120$ billion per annum. (U.S.-China, Economic and Security Review Commission, n.d.) In 2018, bilateral trade was around \$737.1 billion according to the "Office of the United States Trade Representative." (U.S.-China Trade Facts, n.d.)

Since, China joined the "World Trade Organization" (WTO) in 2001, it has attracted more and more volumes of US investment and resources each year. Since 2001, American exports to China in material goods are up by 527\% and exports in services are up by $997 \%$, while US imports from China have risen by $427 \%$ for material goods and $414 \%$ for services. (U.S.-China Trade Facts, n.d.) Such complex economic interdependence between the two states, US and China, has almost ensured peace and stable bilateral relations.

\section{International Organizations}

Liberal Optimists consider international institutions to be the key in facilitating communication, reducing uncertainty on motives, and building trust for reliable formalized commitments between states. Supra-state arrangements of this kind incentivize cooperation and dilute international anarchy, to levels not attainable in their absence. (Keohane, 1984)

China's admission to the "Nuclear Nonproliferation Regime" (1996) and the WTO (2001) further increased its stature as a responsible global as well as regional actor. Even before, China played an important role as the member of the prestigious United Nations Security Council (UNSC). With each day passing, China is greatly integrating within the international system, which is evident from the fact that its membership in "International Governmental Organizations" (IGO) rose from 21 to 52 and in "International Non-Governmental Organizations" (INGO) from 71 to 1,163 between 1977 and 1997. (Lampton, 2001)

For liberal optimists, the growing China and US participation in a thickening network of international institutions promotes exchange and reduces the possibility of misjudgments, which leads to war, if not fostering trust and greater shared understanding. Regional and bilateral issues aside, China's greater participation in global organizations endows it with greater stakes in upholding and stabilizing the prevailing international system. 
More importantly, China's desire to continue enjoying the perks of its participation in the international system gives it little incentive to commit acts that alienate the status quo, such as coming into conflict with the primary beneficiary, guardian and architect of the global order; the US. (Michel, 1999)

\section{Democratization}

Liberals place a lot of value on the domestic nature of regimes, claiming that it dictates foreign behavior. A democratic government derives its power from the masses, which elect leaders it into power and such states foreign policy reflects the public's interest. Since wars, which in turn increase military expenditures, are less efficient in achieving common good, democracies would not go to war with each other. With more democracies in the world today, war as a logical course of action for achieving public interests has diminished significantly. (Elman, 2001)

According to liberal optimists, democratization has already taken root in China, thanks to economic development and growing acceptance to free trade. (Pei, 1995) As ease of living life has increased for the rapidly growing Chinese middle class, the daily struggle for survival is being replaced with more diverse and progressive primary motives that hearken back to the democratic evolution of North American and European societies. (Economy, 2004; Rowen, 1996)

Apart from triggering political aspirations, economic development is a functional precursor to political liberalization. The need for political freedoms is part and parcel of the rule of law as well as the presence of legal contracts and a reliable justice system without which economic development cannot flourish. In order to provide the standard of society and well-being existent within advanced industrialized countries (all of which happen to be democracies), China will inevitably democratize.

Given the symptoms, liberal optimists are hopeful that the Chinese will come about and bilateral ties with the US within the "zone of peace." Undoubtedly, there is still time for such a transformation to culminate, though it is possible for a future democratic China to be as peaceful as the US is with the European Union.

The US President Bill Clinton himself went back on his initial conditionality of tying China's access to the US-markets with human rights mandates. This policy of engagement was also adopted by his opponent and successor; President George W. Bush. (Mann, 1999) The fundamental concept is that trade engenders social equality and consequently democracy, which was reiterated in Bush's 1999 campaign speech, "Economic freedom creates habits of liberty. And habits of liberty create expectations of democracy. . . . Trade freely with China, and time is on our side." (Yagielski, 1999)

Dr. Ruan Zongze, Executive Vice President and Senior Fellow at the China Institute of International Studies, points out how Beijing and Washington once worked together to deter Soviet Union during the latter stages of the Cold War, pledged to fight against terrorism after $9 / 11$ attacks, and effectively stabilized the global economy from a severe financial meltdown of 2008. Since China has put in the effort of integrating itself within the international system; thus, it is a stakeholder in its well-being. Also, that escalating tensions between the two globally dominant economies has sparked a debate and would likely have negative consequences on global trade. It is only natural for a friendly and cooperative relationship to be restored but the US and China. (Blatt, 2018)

\section{Liberal Pessimists}

Liberals too have a pessimistic tradition despite being overwhelmingly optimistic. Liberal Pessimists logic posits that the interaction between states is a reflection of the variable domestic character and political structural which arise out of their respective regimes, like that among autocratic China and democratic US. (Moravcsik, 1997)

\section{China: An Autocratic State?}

How China will ultimately politically transform is unclear, but today's China is neither completely autocratic nor completely democratic, but a mixture, labelled by some as "controlled democracy." China's "one-party system" is clearly authoritarian and maintains its grip on power with questionable legitimacy, relying more on its military and other security agencies to maintain internal order. Its leaders are successors within a socio-economic system, that has all but disappeared since the end of the Cold War and appeals to nationalism than on the freely given support of the governed.

This sort of dynamic would be unstable because in case the economic progress curve flattens out, the incumbent ruling order would lean on nationalistic appeal as the only remaining basis of support. Possible consequences would include creating a narrative for the Chinese people to focus their frustration on other states like Taiwan, Japan or the US.; instead of Beijing. Indeed, analysts from both the US and China believe that Beijing increasingly exhibits inclination to behave this way. (Shambaugh, 1996; Whiting, 1995) 
For liberal pessimists, hyper-nationalistic tendencies that have historically arisen during phases of transformation from autocracy to democracy have led to conflict. China's transition towards a more liberal economic and political system on this pattern might bring it into war with its neighbors, according to Jack Snyder and Edward Mansfield. They are more in favor of stable autocratic regimes, in addition to stable democracies, as both are less susceptible to conflict than transitory states. (D. Mansfield \& Snyder, 2006; Mansfield \& Snyder, 2002)

For Liberal Pessimists, transitory processes within societies increase pressures on political participation, where participatory or representative institutions have not yet developed. In trying to maintain their grip on power, elites will often appeal to militant nationalist rhetoric for rallying mass support and consolidate against rivals. Snyder describes the resort to nationalism as being supplemented with militarism and "the scapegoating of enemies of the nation at home and abroad." (Snyder \& Snyder, 2000) With China being ruled through a centralized political apparatus and given its history, this analysis comes into play.

The irony is that while the road towards a democratic China is likely to be perilous its effect on US-China relations will be more detrimental than if it were to remain an autocracy. Liberal Pessimists do agree that a democratically functioning China, with political parties competing in elections and a free media could transform its ties with the US in the long run. However, they also note that a more democratic China would only have more leeway to behave in ways that are at odds with the US. (Deng \& Wang, 1999; Gilley, 2004; Wang, 1999)

\section{US: A Crusading Democracy?}

It is not just that China's transitory political nature may bring it on a collisional path with the US, but the fact that change itself, especially change in global political status quo, inevitably causes conflict (war). If China does not gradually democratize, it will force the US political regime to come into conflict with it. Like liberal optimists, this argument stems from the "Democratic Peace Theory," whereby democracies are less likely to wage war with fellow democracies, while tending to be hostile towards who they view are non-democratic regimes.

As Michael Doyle famously noted, "The very constitutional restraint, shared commercial interests, and international respect for individual rights that promote peace among liberal societies can exacerbate conflicts in relations between liberal and non-liberal societies." Relations among non-liberal and liberal countries are conducted in an "environment of suspicion" due to "the perception by liberal states that non-liberal states are in a permanent state of aggression against their own people." (Doyle, 1983)

While it may transform into a liberal democracy, China is not one yet and unsurprisingly most Americans look at it with a degree of hostility and mistrust. In this context, disputes over China's abuse of human rights in Xinjiang province for instance and against animals may amount to more than a just a minor nuisance in its rapport with the US-liberals, who tend to look at such differences as deeper symptoms that hold unavoidable significance. From the American point of view, human rights abuses are a dead giveaway for an illiberal, oppressive and thus illegitimate regime that cannot be accorded the trust needed for a stable relationship.

In case the US is hostile towards China for its un-democratic nature, it is likely to assist policies that it considers democratic because it would undermine the Chinese regime, even if it is not in its interests to do so from a realpolitik perspective. Thus, Henry Kissinger's policy during the Nixon administration to detach the US from Taiwan for its corrupt, authoritarian government policies might not be viable anymore. In actions reminiscent of the Cold War, future US-leaders may overlook the extent to which Taiwan is a functioning democracy, even if supporting Taiwan risks degrading US-China ties. Liberals tend to justify the US varying foreign policy by the extent to which liberal ideals hold sway over it at the expense of its own material interests. (Lanxin Xiang, 2001; Mead, 2013)

\section{Interactive Effects}

The different nature of the US and Chinese administrative models could lead to a regressive spiral of mutually reciprocal fear and distrust. On one hand, actions taken by the incumbent Chinese regime such as silencing dissent, persecuting religious minorities, limiting freedom of internet access, or broadcasting threats against other states (especially Taiwan) would merely confirm the US perceptions of it as an authoritarian country. As for the United States government, the current Chinese leadership possibly remains influenced by the idea that the US "engagement" policy is actively undermining its legitimacy and seeks to ultimately overthrow it via a seemingly "peaceful" evolutionary process. (Shambaugh, 1996; Zhang \& Austin, 2014) These would include actions by American citizens or Congress including, but not limited to criticism of Beijing's domestic policies, sponsoring Radio Free Asia, broadcasting statements supporting Taiwan, or sympathizing with opposing parties in China's external dealings. 
While realists tend to ignore the character of regimes completely, animosities rooted in ideological differences have a part to play in the cycle of mutual suspicion underlining the US-China ties today. Some Liberal pessimists would also argue that the situation is exacerbated by the presence of groups within China, which specific bureaucratic interests coincide with the interests of groups within the US which stand to capitalize from strained US-China relations. These groups utilize whatever influence to lobby for more hostile policies, exploiting otherwise benign rhetoric, to push their agenda. Such "hawks" can have the unintended effect of reinforcing insecurities preventing more stable relations from being achieved. It is important not to overlook the impact of these groups when speaking about the prospects for harmony among China and the US. (Lampton, 2001; Saunders, 2000)

According to Gordon G. Chang, columnist and author of "The Coming Collapse of China", China and the US have incompatible interests due to which the two titans are fated to come into intense competition, if not conflict. (Chang, 2002) Chang prefers to label China as "revolutionary" and not "revisionist" state, owing to the actions of state media praising Xi Jinping's "unique views on the future development of mankind" similar to those during the Maoist era.

China's rulers, have over the past few decades, increasingly acted with impunity, injuring US personnel and staff while tormenting US ships and aircraft. Some of their actions include seizing an American vessel from international water, while interfering with many others. China has over the years stolen billions of dollars in American intellectual property. As a state, China reneges on its obligations to other states while expecting others to honor obligations to theirs. They are engaging in nothing less than an assault on the world's rules-based order.

For the last 150 years, the US leaders have been content on drawing the US western defense boundary well off Asia's coast. China upends this long-standing arrangement by actively undermining the US allies in the region, interfering in US-interests. Such consistent efforts not only are a direct assault on the rules and regulations of the prevailing global system, but also directly undermine US security. Therefore, a rising China is a multi-dimensional and existential threat and the knee-jerk response to it would be intervention of some sorts by the status quo powers.

\section{Conclusion}

In contemporary times, the nature of US-China relations is clearly a hybrid, comprising of diverse cooperative and competitive elements. On a daily basis, this relationship could be represented on a spectrum that ranges from complete collaboration to unreserved competition - maybe war. (Friedberg, 2005) In either case, there exists a reiteration on part of the status quo, either through coercion/containment or gradual rollback/economic slowdown.

"Simple paradigmatic preponderance" is where opposing arguments believe certain mechanisms are theorized because their significance outweighs the effects of opposing or reinforcing forces. Thus, realist assumptions will draw on history and inherent nature of the world state system, while criticizing liberal ideas of peace, cooperation and progressiveness, to posit that war is inevitable.

Another, more probable, prospect is that the US-China future relations will be determined by the synergistic effects of similarly oriented causal forces. It is apparent that mechanisms, such as economic competition becoming a platform for inter-state rivalry rather than conventional war. Also, the shared perception of hostile images projected by the US and China of one another, are common themes across the pessimist spectrum. Similar conclusions are also reached by the optimists that certain realist and liberal mechanisms are catalysts for peace and see little possibility for outright confrontation.

The US blames China for the ever-growing disorder in the prevailing liberal world order. Since China joined the WTO, it has reaped maximum benefits, whereas it has failed to meet the obligations set by the commerce and trade global institute. America under President Trump, in its 'National Security Strategy,' has keenly noted China's free riding in global institutes, forced technology transfer, theft of intellectual property, and it still supporting state capitalism; thus, deemed China as a "strategic competitor" which has to be contained. In reaction, China, under President XI Jinping, has further tightened its grip on domestic and foreign affairs. Furthermore, the trade wars may have started as a ploy of the US to force China's hand, but now has escalated into a rapidly growing state of hostility between the two states.

To curb China's influence, not only is the US trying to restrict Chinese foreign direct investment in sensitive areas, but also in order to guarantee West's supremacy in strategic industries, like 5G and artificial intelligence, it is exhausting all resources on hand. Also, the US is forcing its allies not to take part in China's massive "Belt and Road Initiative" (BRI). In addition, it has increased its navy's patrols in both the South and East China seas. If 
the US continues to derail the growth of China, while China aggressively continues to project its power; a cold war will most definitely begin, if already it has not started, and the probability of a conventional war (via proxies) cannot be ruled out. If this happens, the 'Thucydides Trap' would swallow not just the two confronting states, the US and China, but the entire world.

So far, China has maintained that its top priority remains human and economic development for which it is heavily investing in regional infrastructural projects, such as BRI. BRI, once complete, will allow China to secure strategic access to the Middle East by bypassing infamous the "Straits of Malacca," and open up Central Asia and subsequently European markets. Conflict among the US and China cannot be ruled out in this case, as China will be encroaching in US dominated markets; thus, a proxy war between China and US on a variety of dimensions, $5^{\text {th }}$ generation war, is highly likely.

Beijing and Washington's struggle for power is now being channeled through patronization or regime changes all over the world mostly covertly. For instance, in both Myanmar and Sri Lanka, regimes that were sympathetic to China's cause, regional interconnectivity in the shape of BRI, were toppled by the US, with India's help, and pro-US regimes of Aung San Suu Kyi in Myanmar and Mahinda Rajapaksa in Sri Lanka were established. But some theatres for overt warfare could be possible, like in the Korean Peninsula, which remains the only conceivable battlefield where the US and China would clash with conventional arms. China's willingness to utilize alternative markets; forcing North Korea to the bargaining table, is a clear sign of China diffusing rather than escalating a war. Other possible areas for conflict between the two states could be the South China Sea, Taiwan, the Diaoyu Islands, and naval blockades across the Malacca and Hormuz Straits.

These scenarios still do not rule out the continuity of substantial economic ties among China and the US, even amidst their security competition. As the Cold War managed to contribute to globalization and eventually ended non-violently, we can look forward to seeing the unipolar order preserved or even complemented by rising China. The two Great Powers may even cooperate on many issues, such as anti-terrorism, environmental preservation and technological innovation through competition. With both states being nuclear capable states, the option of a full-fledged conventional war is completely ruled out. Most likely, the nature of future US-China relations will be a mixture of economic cooperation and competition with a hint of political and security confrontation, with the US being the dominant partner.

\section{References}

Allison, G. (2017). Destined for War: Can America and China Escape Thucydides's Trap? Houghton Mifflin Harcourt. Retrieved

from https://www.amazon.com/Destined-War-America-Escape-Thucydidess-ebook/dp/B01IAS9FZY

Anderson, J., \& Keidel, A. (2005). China: Things Get Ugly. Carnegie Middle East Center. Retrieved from https://carnegie-mec.org/2005/07/01/china-things-get-ugly-event-793

Artiga-Valencia, R. (2019, July 18). The U.S. Spends More on Its Military Than 144 Countries Combined. National Priorities Project. Retrieved from https://www.nationalpriorities.org/blog/2019/07/18/us-spends-more-its-military-176-countries-combined/

Balding, C. (2019, March 20). What's Causing China's Economic Slowdown. Retrieved from https://www.foreignaffairs.com/articles/china/2019-03-11/whats-causing-chinas-economic-slowdown

Bernstein, R., \& Munro, R. H. (1998). The Coming Conflict with China (Reprint edition). Vintage.

Blatt, M. (2018, July 30). America and China: Destined for Conflict or Cooperation? We Asked 14 of the World's Most Renowned Experts [Text]. The National Interest. Retrieved from https://nationalinterest.org/feature/america-and-china-destined-conflict-or-cooperation-we-asked-14-worlds -most-renowned-experts

Brooks, S. G., \& Wohlforth, W. C. (2002, August). American Primacy in Perspective. Foreign Affairs. Retrieved from https://www.foreignaffairs.com/articles/united-states/2002-07-01/american-primacy-perspective

Bush, G. W. (2009). The National Security Strategy of the United States of America. Wordclay.

Chang, G. G. (2002). The Coming Collapse of China. Arrow.

Choucri, N., \& North, R. (1975). Nations in Conflict: National Growth and International Violence. W H Freeman $\&$ Co.

Christensen, T. J. (1999). China, the US-Japan alliance, and the security dilemma in East Asia. International Security, 23(4), 49-80. 
Christensen, T. J. (2000). Theater Missile Defense and Taiwan's Security. Orbis, 44(1), 79-79.

D. Mansfield, E., \& Snyder, J. (2006). Electing to Fight: Why Emerging Democracies Go To War (Vol. 43).

Deng, Y., \& Wang, F.-L. (1999). In the Eyes of the Dragon: China Views the World. Rowman \& Littlefield.

Doyle, M. W. (1983). Kant, Liberal Legacies, and Foreign Affairs. Philosophy \& Public Affairs, 12(3), 205-235. JSTOR.

Doyle, M. W. (1986). Liberalism and World Politics. The American Political Science Review, 80(4), 1151-1169. JSTOR. https://doi.org/10.2307/1960861

Doyle, M. W. (1997). Ways of War and Peace: Realism, Liberalism, and Socialism. Norton.

Economy, E. (2004). Don't Break the Engagement. Foreign Affairs, 83(3), 96-109. JSTOR. https://doi.org/10.2307/20033978

Elman, C. (2001). Introduction: History, Theory, and the Democratic Peace. The International History Review, 23(4), 757-766. JSTOR.

Eyraud, H. (2004). Ross Terrill, The New Chinese Empire-And what it means for the United States. New York, Basic Books, 2003, 384 p. China Perspectives, (52). Retrieved from http://journals.openedition.org/chinaperspectives/809

Fabey, M. (2017). Crashback: The Power Clash Between the U.S. and China in the Pacific. Scribner.

Friedberg, A. L. (2002). 11 September and the future of Sino-American relations. Survival, 44(1), 33-50. https://doi.org/10.1080/00396330212331343222

Friedberg, A. L. (2005). The Future of U.S.-China Relations: Is Conflict Inevitable? International Security, 30(2), $7-45$.

Fukuyama, F. (2006). The End of History and the Last Man. Simon and Schuster.

Gill, B., \& Kim, T. (1995). China's Arms Acquisitions from Abroad: A Quest for "Superb and Secret Weapons." Oxford University Press.

Gilley, B. (2004). China's Democratic Future: How It Will Happen and Where It Will Lead. Columbia University Press; JSTOR. Retrieved from https://www.jstor.org/stable/10.7312/gill13084

Gilplin, R. (1981). War and Change in World Politics. Cambridge University Press. https://doi.org/10.1017/CBO9780511664267

Glaser, B. S. (2005). U.S.-China Relations: Rice Seeks to Caution, Cajole, and Cooperate with Beijing. 7(5). Retrieved from https://csis-prod.s3.amazonaws.com/s3fs-public/legacy_files/files/media/csis/pubs/0501qus_china.pdf

Goldstein, A. (1998). Great Expectations: Interpreting China's Arrival. International Security, 22(3), 36-73. https://doi.org/10.1162/isec.22.3.36

Goldstein, A. (2005, May 11). Rising to the Challenge: China's Grand Strategy and International Security. East-West Center. Retrieved from https://www.eastwestcenter.org/publications/rising-challenge-china\%E2\%80\%99s-grand-strategy-and-inter national-security

Gries, P. H. (2004). China's New Nationalism: Pride, Politics, and Diplomacy (1st ed.). University of California Press; JSTOR. Retrieved from https://www.jstor.org/stable/10.1525/j.ctt1pq06f

Harris, S. (2003). Does China matter? The Global economic Issues. Retrieved from https://core.ac.uk/download/pdf/156614860.pdf

Huntington, S. P. (1991). America's Changing Strategic Interests. Survival, 33(1), 3-17.

Ikenberry, G. J. (2015, September 15). The Rise of China and the Future of the West. Retrieved from https://www.foreignaffairs.com/articles/asia/2008-01-01/rise-china-and-future-west

Jervis, R. (1978). Cooperation Under the Security Dilemma. World Politics, 30(2), 167-214. JSTOR. https://doi.org/10.2307/2009958

Jervis, R. (1990). The Meaning of the Nuclear Revolution: Statecraft and the Prospect of Armageddon (1st ed.). Cornell University Press.

Jervis, R. (1998). Realism in the Study of World Politics. International Organization, 52(4), 971-991. JSTOR. 
Johnston, A. I. (2003). Is China a Status Quo Power? International Security, 27(4), 5-56. JSTOR.

Kang, D. C. (2005). Hierarchy in Asian international relations: 1300-1900. Asian Security, 1(1), 53-79.

Karmel, S. (2000). China and the People's Liberation Army-Great Power or Struggling Developing State? (2000 ed.). Palgrave Macmillan. Retrieved from https://www.palgrave.com/gp/book/9780312223892

Keohane, R. O. (1984). After Hegemony: Cooperation and Discord in the World Political Economy. Princeton University Press. JSTOR. Retrieved from https://www.jstor.org/stable/j.ctt7sq9s

Kissinger, H. (2002). Does America Need a Foreign Policy?: Toward a Diplomacy for the 21st Century (1st ed.). Simon \& Schuster.

Lampton, D. M. (2001). Same Bed, Different Dreams: Managing U.S.- China Relations, 1989-2000 (1st ed.). University of California Press; JSTOR. Retrieved from https://www.jstor.org/stable/10.1525/j.ctt1 pnxzb

Lanxin Xiang. (2001). Washington's Misguided China Policy. Survival, 43(3), 7-24. https://doi.org/10.1080/00396338.2001.9688541

Lardy, N. R. (2013, January 10). China's Unfinished Economic Revolution. Brookings. Retrieved from https://www.brookings.edu/book/chinas-unfinished-economic-revolution/

Maddison, A. (1998). Chinese Economic Performance in the Long-Run (2nd ed.). Development Centre Studies. Retrieved from http://www.piketty.pse.ens.fr/files/Maddison07.pdf

Mann, J. (1999). About Face: A History of America's Curious Relationship with China from Nixon to Clinton. Alfred Knopf.

Mansfield, E. D., \& Snyder, J. (2002). Democratic Transitions, Institutional Strength, and War. International Organization, 56(2), 297-337. JSTOR.

McDevitt, M. (2000). Beijing's Bind (Vol. 23). https://doi.org/10.1162/016366000561079

Mead, W. R. (2013). Special Providence: American Foreign Policy and How It Changed the World. Routledge.

Mearsheimer, J. J. (2003). The Tragedy of Great Power Politics (Updated Edition). W. W. Norton.

Medeiros, E. S. (2001). Ballistic Missile Defense and Northeast Asian Security. Retrieved from https://www.nonproliferation.org/wp-content/uploads/2014/01/ballistic_missile_defense_northeast_asian_se curity.pdf

Medeiros, E. S., Cliff, R., Crane, K., \& Mulvenon, J. C. (2005). A New Direction for China's Defense Industry. Rand Corporation.

Michel, O. (1999). China Joins the World: Progress and Prospects. Council on Foreign Relations.

Moravcsik, A. (1997). Taking Preferences Seriously: A Liberal Theory of International Politics. International Organization, 51(4), 513-553.

Mosher, S. (2002). Hegemon: China's Plan to Dominate Asia and the World. Encounter Books.

Nathan, A. J. (2000). What's wrong with American Taiwan policy. The Washington Quarterly, 23(2), 91-106. https://doi.org/10.1162/016366000560980

Nathan, A. J., \& Ross, R. S. (2009, January 28). The Great Wall and the Empty Fortress: China's Search for Security. $\quad$ Retrieved from https://www.foreignaffairs.com/reviews/capsule-review/1997-07-01/great-wall-and-empty-fortress-chinas-s earch-security

O’Hanlon, M. (2000). Why China Cannot Conquer Taiwan. International Security, 25(2), 51-86. JSTOR.

Pei, M. (1995). “Creeping Democratization" in China. Journal of Democracy, 6(4), 65-79. https://doi.org/10.1353/jod.1995.0070

Pumphrey, C. W. (2002). The Rise of China in Asia: Security Implications. Carlisle, PA: Strategic Studies Institute, U.S. Army War College. Retrieved from https://trove.nla.gov.au/version/36797781

Rawski, T. (2001). What's happening to China's GDP statistics? (Vol. 12).

Ross, R. S. (1999). The Geography of the Peace: East Asia in the Twenty-First Century. International Security, 23(4), 81-118. JSTOR.

Rowen, H. S. (1996, September 1). The Short March: China's Road to Democracy [Text]. The National Interest. $\mathrm{https} / / /$ nationalinterest.org/article/the-short-march-chinas-road-to-democracy-416 
Roy, D. (2000). Tensions in the Taiwan Strait. Survival, 42(1), 76-96. https://doi.org/10.1093/survival/42.1.76

Russett, B., \& Oneal, J. R. (2002). Triangulating Peace: Democracy, Interdependence and International Organizations (Vol. 19). https://doi.org/10.2307/20753346

Saunders, P. C. (2000). China's America Watchers: Changing Attitudes towards the United States. The China Quarterly, 161, 41-65. JSTOR.

Schweller, R. (1999). Managing the Rise of Great Powers: History and Theory.

Shambaugh, D. (1996). Containment or Engagement of China? Calculating Beijing's Responses. International Security, 21(2), 180-209. JSTOR. https://doi.org/10.2307/2539074

Shambaugh, D. (1999). China's Military Views the World: Ambivalent Security. International Security, 24(3), 52-79. JSTOR.

Snyder, J. L., \& Snyder, P. J. L. (2000). From Voting to Violence: Democratization and Nationalist Conflict. Norton.

Swanson, A. (2020, February 5). U.S. Trade Deficit Shrinks, but Not Because Factories Are Returning. The New York Times. Retrieved from https://www.nytimes.com/2020/02/05/business/economy/trump-trade.html

Tao, W. (Ed.). (2018). The US Policy Making Process for Post Cold War China: The role of US Think Tanks and Diplomacy. Springer Singapore. Retrieved from https://www.springer.com/gp/book/9789811049736

The People's Republic of China. (2018). Office of the United States Trade Representative. Retrieved from https://ustr.gov/countries-regions/china-mongolia-taiwan/peoples-republic-china

Tyler, P. E. (1999, August 22). Who's Afraid of China? New York Times Magazine. Retrieved from https://www.nytimes.com/1999/08/22/magazine/l-who-s-afraid-of-china-087556.html

U.S.-China, Economic and Security Review Commission. (n. d.). Retrieved July 9, 2019, from https://www.uscc.gov/

U.S.-China Trade Facts. (n. d.). Office of the United States Trade Representative.

Waltz, K. N. (2010). Theory of International Politics (1st ed.). Waveland Press.

Wang, F.-L. (1999). Self-Image and Strategic Intentions: National Confidence and Political Insecurity. In the Eyes of the Dragon: China Views the World, 21-46.

Whiting, A. S. (1995). Chinese Nationalism and Foreign Policy after Deng. The China Quarterly, 142, 295-316. JSTOR.

Wohlforth, W. C. (1999). The Stability of a Unipolar World. International Security, 24(1), 5-41. JSTOR.

Wolf, C., \& Chen, S. (Eds.). (2001). China, the United States, and the Global Economy. Rand.

Yagielski, J. (1999, November 19). Bush Lays Out Foreign Policy Vision. CNN. Retrieved from http://edition.cnn.com/ALLPOLITICS/stories/1999/11/19/bush.speech/index.html

Yang, L. (2013). China's Growth Miracle: Past, Present, and Future. United Nation Research Institute for Social Development, 17.

Zhang, Y., \& Austin, G. (2014). Power and Responsibility in Chinese Foreign Policy. ANU E Press.

\section{Copyrights}

Copyright for this article is retained by the author(s), with first publication rights granted to the journal.

This is an open-access article distributed under the terms and conditions of the Creative Commons Attribution license (http://creativecommons.org/licenses/by/4.0/). 